\title{
Low-flow vascular malformation
}

\section{Contribution of sequential postcontrast MRI acquisitions}

\section{Figure $1 \quad$ MRI and digital subtraction angiography}
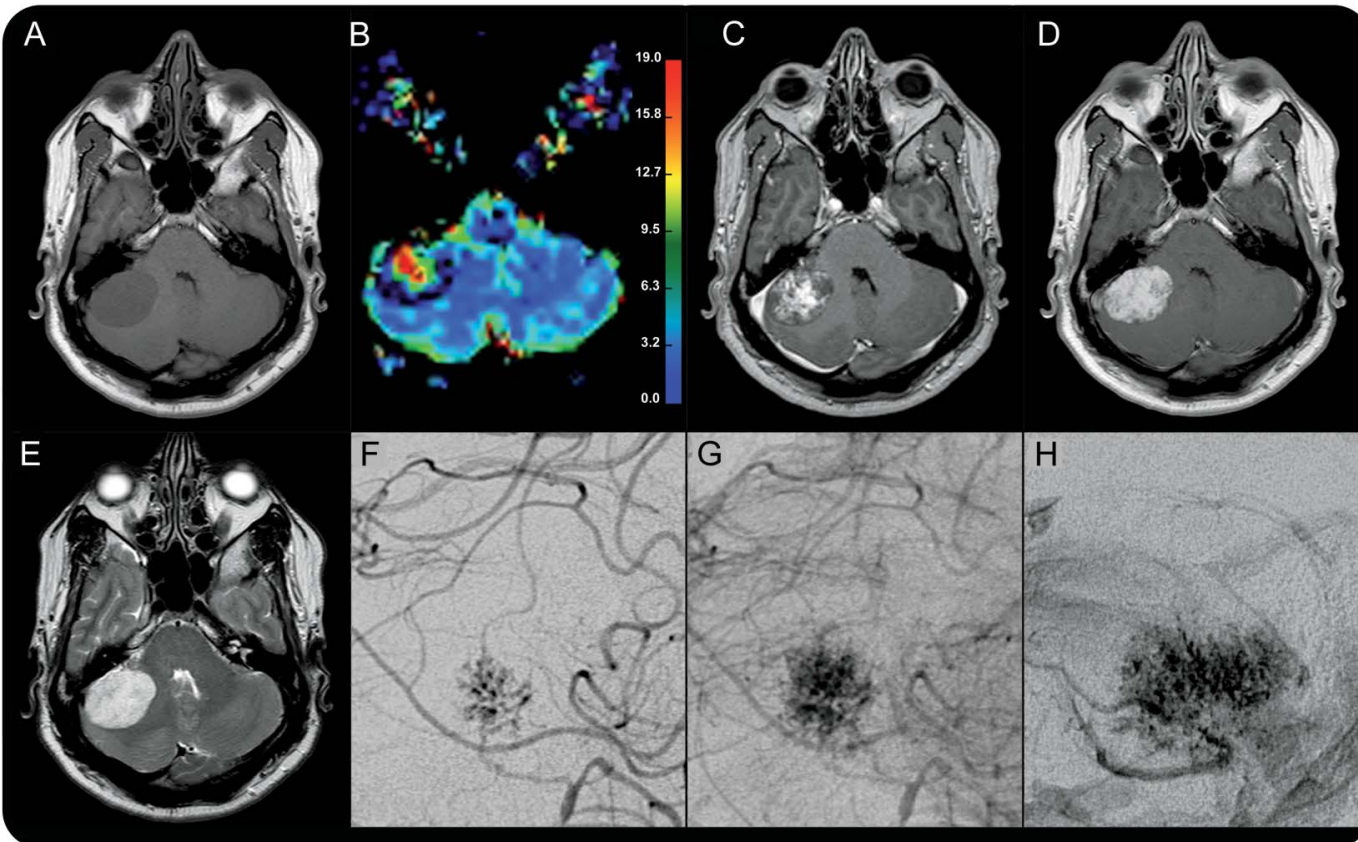

H

T1-weighted imaging (A) and T2-weighted imaging (E). Central high perfusion on the cerebral blood volume map (dynamic susceptibility contrast perfusion) (B), progressive enhancement on T1-weighted imaging immediately after injection (C), and 5 minutes later (D). Progressive vascular filling on digital subtraction angiography: arterial phase (F), intermediate phase $(\mathrm{G})$, and late phase $(\mathrm{H})$.

A 50-year-old man was referred for subacute intracranial hypertension. MRI revealed a well-circumscribed lesion in the posterior fossa that was hypointense on T1-weighted imaging and hyperintense on T2-weighted imaging (figure 1, A and E). Cerebral blood volume map and sequential postcontrast T1-weighted images showed progressive increase in the homogeneity of the contrast enhancement, indicating that the lesion had low but substantial flow (figure 1, B-D). Digital subtraction angiography showed a vascular lesion with a central to peripheral pattern of vascularity and absence of early venous return (figure 1, F-H). The lesion was resected. Pathologic examination revealed a capillary-venous malformation (figure 2). ${ }^{1,2}$ This case highlights that MRI can identify low flow in vascular malformations.

Olivier Heck, MD, Alexandre Krainik, MD, PhD, Kamel Boubagra, MD, Florence Tahon, MD, Arnaud Attye, MD, Jean François Le Bas, MD, PhD, Jean Boutonnat, MD, PhD, Sylvie Grand, MD

From the Departments of Neuroradiology and MRI (O.H., A.K., K.B., F.T., A.A., J.F.L.B., S.G.), University Hospital of Grenoble; the Department of Diagnostic and Interventional Neuroradiology (O.H.), University Hospital of Nancy; and the Department of Pathology (J.B.), University Hospital of Grenoble, France.

Author contributions: Dr. Heck: design and conceptualization of the study, analysis and interpretation of the data, drafting and revising the manuscript for intellectual content. Dr. Krainik: revising the manuscript for intellectual content. Dr. Boubagra: analysis and interpretation of the data. Dr. Tahon: analysis and interpretation of the data. Dr. Attye: revising the manuscript for intellectual content. Dr. Le Bas: revising the manuscript for intellectual content. Dr. Boutonnat: analysis and interpretation of the data. Sylvie Grand: design and conceptualization of the study, analysis and interpretation of the data, drafting and revising the manuscript for intellectual content. Study funding: No targeted funding reported. 


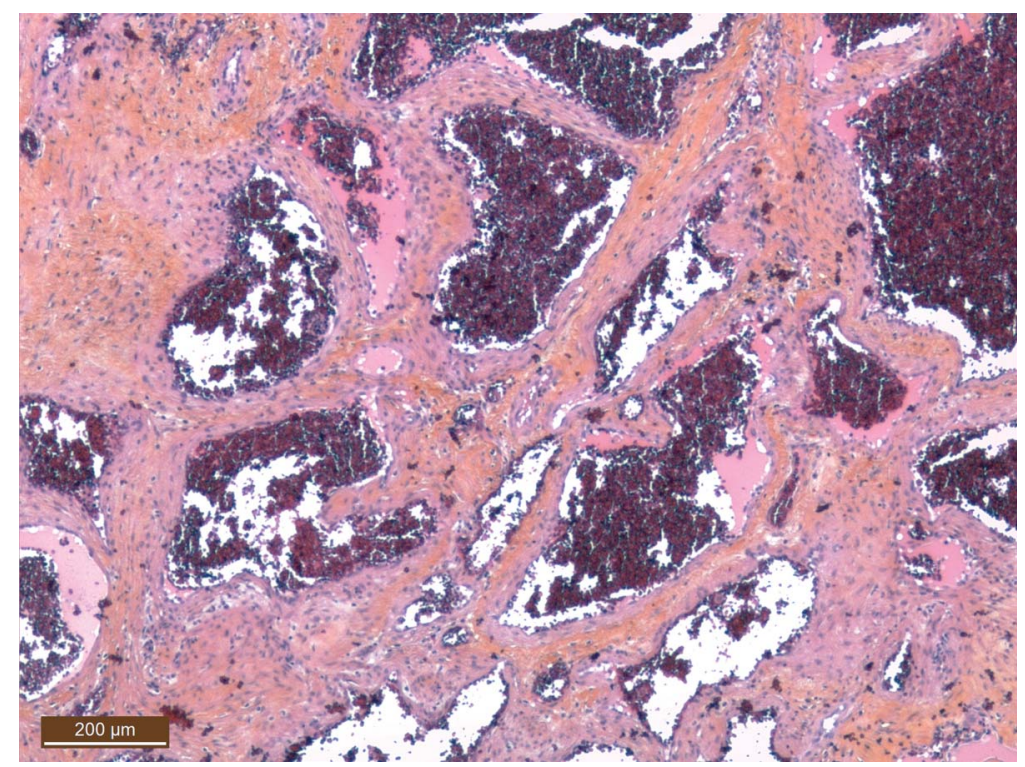

Paraffin-embedded section stained with hematoxylin \& eosin-Safran shows large blood vessels with thin walls. Absence of proliferating cells; no expression of GLUT1. This can be defined as capillary-venous malformation according to the International Society for the Study of Vascular Anomalies classification system.

Disclosure: The authors report no disclosures relevant to the manuscript. Go to Neurology.org for full disclosures.

Correspondence to Dr. Heck: olivier.heck1@gmail.com

1. Lowe LH, Marchant TC, Rivard DC, et al. Vascular malformations: classification and terminology the radiologist needs to know. Semin Roentgenol 2012;47:106-117.

2. Flors L, Leiva-Salinas C, Maged IM, et al. MR imaging of soft-tissue vascular malformations: diagnosis, classification, and therapy follow-up. Radiographics 2011;31:1321-1340.

\section{WriteClick: Rapid Online Correspondence}

The editors encourage comments about recent articles through WriteClick:

Go to www.neurology.org and click on the "WriteClick" tab at the top of the page. Responses will be posted within 72 hours of submission.

Before using WriteClick, remember the following:

- WriteClick is restricted to comments about studies published in Neurology within the last eight weeks

- Read previously posted comments; redundant comments will not be posted

- Your submission must be 200 words or less and have a maximum of five references; reference one must be the article on which you are commenting

- You can include a maximum of five authors (including yourself) 


\section{Neurology}

\section{Low-flow vascular malformation: Contribution of sequential postcontrast MRI acquisitions \\ Olivier Heck, Alexandre Krainik, Kamel Boubagra, et al. Neurology 2014;83;100-101 \\ DOI 10.1212/WNL.0000000000000544}

This information is current as of June 30, 2014

Updated Information \& Services

References

Subspecialty Collections

Permissions \& Licensing

Reprints including high resolution figures, can be found at: http://n.neurology.org/content/83/1/100.full

This article cites 2 articles, 0 of which you can access for free at: http://n.neurology.org/content/83/1/100.full\#ref-list-1

This article, along with others on similar topics, appears in the following collection(s):

MRI

http://n.neurology.org/cgi/collection/mri

Other cerebrovascular disease/ Stroke

http://n.neurology.org/cgi/collection/other_cerebrovascular_disease_st roke

Information about reproducing this article in parts (figures,tables) or in its entirety can be found online at:

http://www.neurology.org/about/about_the_journal\#permissions

Information about ordering reprints can be found online:

http://n.neurology.org/subscribers/advertise

Neurology ${ }^{\circledR}$ is the official journal of the American Academy of Neurology. Published continuously since 1951, it is now a weekly with 48 issues per year. Copyright @ 2014 American Academy of Neurology. All rights reserved. Print ISSN: 0028-3878. Online ISSN: 1526-632X.

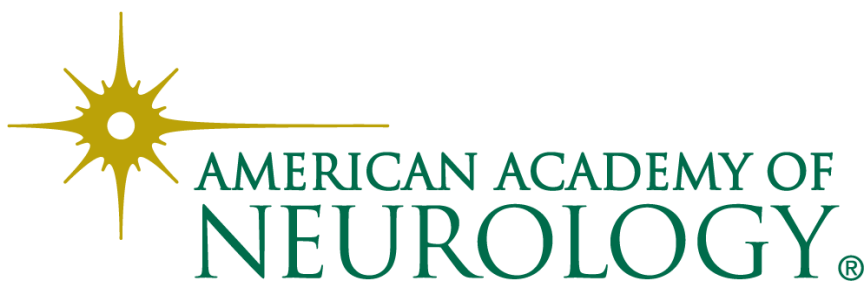

